\title{
Livestock-Environment Interaction: Issues and options in Nigeria
}

\section{ORHERUATA, A.M.; OMOYAKHI, J.M. ${ }^{\#}$}

Department of Animal Science, Faculty of Agriculture, University of Benin, Benin City, Edo State, Nigeria.omoyank@yahoo.com

\begin{abstract}
The demand, production and consumption of livestock products are growing faster than the increase in world population. This development has led to pollution problem caused by the increasing amount of animal waste. The complaints and health threats of animal waste pollution to our environment is on the increase. In some cases, the damage has been spectacular and even tragic. In Nigeria, there is absence of true figures of waste produced but the environmental consequences and hazards are enormous and obvious. It is now glaring therefore that haphazard livestock management is synonymous with hazardous environment and hazardous economy and society. An objective, consistent and continuous maintained environment-livestock management is the only answer to our problem of environmental protection for us today and our children tomorrow. @ JASEM
\end{abstract}

Livestock provide essential commodities and services to the majority of the World's population. With increasing number of people, meat production is projected to increase from 200 million to 310 million tons per year by the year 2020 (De Haan et al., 1996). Although demand for livestock products is stagnated in developed countries, it is rapidly increasing elsewhere due to urbanization and associated shift in eating habits towards livestock products. The demand and consumption of livestock products are growing even faster than the increase in world population. Such demand has called for development of the livestock industry. The development also leads to pollution problem caused by the increasing amount of animal waste. The complaints of animal waste pollution is on the increase and has reached its peak in developed countries like Japan since 1973 (Harada, 1994). Rising affluent, particularly in the developing countries where average real incomes have doubled since the early 60's, means that more people can afford the high valued protein that livestock can offer. What affect is the demand for meat, milk and eggs going to have on the environment? Obviously, in spite of their growing global importance, livestock are increasingly being held responsible for many adverse effects on the environments. Loss of vegetation cover, reduced biodiversity, soil erosion and compaction and excessive run-off often from overgrazing. High concentrations of livestock contribute to contamination of ground water, eutroplication and soil pollution. Livestock can produce significant quantities of "greenhouse" gases thereby possibly contributing to global warming (Anon, 1982). The objective of this presentation will be to look at livestock production and its environmental impact and also look at waste management strategies and to proffer control policies as part of the continuing effort to create total environmental sanity and generate spontaneous environmental protection measures through proper and effective environmentallivestock management.

\section{ENVIRONMENTAL CONSEQUENCES} Livestock production and waste

As livestock production increases worldwide, livestock waste is becoming a serious environmental hazard. In some cases, the damage has been spectacular and even tragic. In June, 1995, the artificial lagoon at a hog farm in North Carolina burst. The sudden release of nearly 100 million litres of hog urine and feaces polluted neighbouring communities and killed millions of fish in nearby rivers. In 2000, drinking water contamination by livestock waste led to several deaths in Canada town of Walkerton (Catelo et al., 2001). Environmental hotspots for poultry production reflect the environmental distortion and interference caused by livestock production. Surveys conducted in Benin City, Nigeria showed that although economic performance is competitive, most producers are operating outside the boundaries of sustainability because of inadequate waste management and excessive waste produced in small geographical areas, beyond the assimilation capacity of the local environment. With smallholders farmers, waste could be applied to land used to produce food and other crops. But with development and specialization in livestock production that requires large herds, waste may exceed the carrying capacity of local ecosystem and are a potential cause of a number of pollution and health problems related to their organic matter, nutrients, pathogens, odours, dust and air borne micro-organisms (Zlang \& Felmann, 1997).

In Nigeria, there is absence of true figures of waste produced. This is not evidence of absence as the environmental consequences and hazards are enormous and obvious. Itodo et al., (2000) estimated 1.4 million, 6.40 million and 5.2 million kilogram of cattle, poultry and piggery manure per day respectively. Sangodoyin (1996) also noted that the quantity of waste vary with species. He put daily manure of animal/day as 30.00, 15.00, 1.10 and 0.12 for dairy cattle, beef cattle, pigs and layers respectively. This is still a fraction of the Nigerian livestock. In most cases, scientists and producers are rarely concerned on the waste management but rather on increase production. It is commonly observed in major farms in Nigeria that animal 
waste discharges by backyard in commercial piggeries and poultry farms run into rivers and erosion courses. These contribute a substantial amount to river pollution. Generally, livestock production and their waste have polluted the environmental in various ways:

\section{Air pollution}

Air is one of the major livestock related environmental problems under industrial system. Air pollution has serious repercussions and damage to health occurs as pollutants molecules interact unfavourably with the intricate molecules and fluids of the human body (Ademoroti, 1996). Air pollution and global warming are produced by livestock directly and indirectly. The production of livestock has significantly contributed to the increase levels of $\mathrm{CO}_{2}$ and other greenhouse gases during the past 250 years (Darwin, 2001). About $40 \%$ of emitted methane is produced by agriculture predominantly by ruminant animals (Rosenzweig \& Hillel, 1998).

\section{Land degradation}

Land degradation such as deforestation, soil quality and desertification are excessive global problems. The global assessment of soil degradation, Oldeman, et al. (1991) estimates that 680 hectares of rangeland have become degraded. In Nigeria, prolong heavy grazing contributes to the disappearance of edible plant species and subsequent dominance by either inedible, herbaceous plants or bushes. Excessive grazing has also caused soil compaction and erosion, decrease soil fertility and water infiltration and the loss of organic matter content. The recent increase in the rate of desertification may not be unconnected with excessive grazing in Northern Nigeria. Livestock impact on the soil can be classified into two broad categories as reported by Whitmore (2001); physical impact of the animal on the soil as it moves around and secondly, the chemical and biological impact of the feaces and urine that the animal deposits on the soil.

\section{Physical impact}

Heavy livestock, such as cattle compact soil structures and destroy vegetation on which they graze. Destruction of soil structure and vegetation is harmful because restoration does not occur immediately the grazing animals are withdrawn. The problems with soil structure are not limited to cattle farming. Pig production is notorious for its destructive effects on vegetation as part of the pig's behaviour to dig into the soil in extensive system common among rural farmers.

\section{Chemical and biological impacts of manure and urine}

Although impacts of livestock manure has been seen to have impact on water and the atmosphere, soil is an intermediary. The amount of urine declared by a grazing cow is of the order 2 liters applied to an area of about $0.4 \mathrm{~m}^{2}$ (Addiscoth et al.,
1991). This represents an instantaneous application of 400 to $1,200 \mathrm{~kg} \mathrm{~N}$ per hectare. Such an amount burns vegetation and is often toxic to plant roots which cannot immediately recover to take the nitrogen (full recovery can take up to 12 months) and the problem worse in areas where animals congregate (Early, et al., 1995).

\section{Heavy metals}

Copper and zinc which are essential minerals for livestock diets are deliberately added to concentrate feeds whereas other heavy metals in particular cadmium, are introduced involuntarily via feed phosphates. Only 5 to $15 \%$ of metals additive are absorbed by animals, the rest are excreted. Soils on which pig and poultry manures are continuously applied at high rates accumulate heavy metals jeopardizing the good functioning of the soil, contaminating crops and posing human health risk (Conway \& Pretty, 1991).

\section{Socio-economic problems}

The extensive system of animal production especially by the Nomadic Fulani which houses over $90 \%$ of the ruminant animals has continued to pose serious threat to crop farming in Nigeria. The migration system imposed upon this ruminant production by climatic factors results in animals trampling and eating existing or growing crops on the field. Fulani herdsmen most often sent the bush on fire destroying crops and damaging the ecosystem. There have been several reports of clashes between the herdsmen and the crop farmers leading to loss of lives, displacement of settlements and destruction of valuable property.

\section{ECONOMIC OF ENVIRONMENTAL AND LIVESTOCK MANAGEMENT}

From the discussion so far, it is glaring that haphazard livestock management is synonymous with hazardous environment and hazardous economy and society. Many production systems had been at a sustainable equilibrium with livestock being produced in harmony with nature and environmentally sound systems. However, over the last decade, several production systems and growing concern for increase livestock production have lost this equilibrium because of the pressure caused by growing human population and increased demand for animal products. To get this right, the appropriate environmental friendly livestock management must be inculcated in the production system.

\section{(i) Environmental awareness campaign}

The level of environmental awareness among livestock farmers is low as majority of the people are environmentally illiterate. They have little or no regard to biodiversity and aesthetics. This has to be improved through publications, workshops, radio and television jingles and personal touch. It should be down to earth so that the people can understand and realize the need for action. 
(ii) Environmental pollution laws

There is the need to widen the scope and review the dimensions of the responsibility of the Federal Environmental Protection Agency in line with what happens in other developed countries. Appropriate laws must be passed and measures put in place to punish erring farmers.

(iii) Livestock waste management financing

The problem of livestock waste is quite enormous. Much of the constraints is lack of Governmental involvement. Government's assistance would serve as a good incentive to poor farmers and would further boost production efficiency thereby reducing the high cost of production. Substantial budget must therefore be allocated to livestock waste management and the implementation supervised by a nucleus of waste management experts.

\section{(iv) Control of commercial/industrial livestock production}

There should be laws strictly limiting commercial livestock production to rural or remote areas. Commercial livestock activities within urban areas constitute major environmental hazards. In most cases, rural farms are soon enveloped by residence through development and urbanization, Government must assist in relocating such farms.

\section{(v) Livestock production system}

In practice, close grazing system (under extensively system) where the waste products are used within the system and does not present a burden on the environment should be adopted by the farmers. Government should help to establish more functional ranches and monitor the activities of livestock in such establishments. Mixed farming which integrates crop and livestock production should be encouraged. According to FAO (1996), mixed farming is probably the most benign agricultural system from an environmental perspective because it is partially, at least, a closed system. This allows intensified farming with less dependence on natural resources and preserving more biodiversity.

\section{(vi) Processing waste through the use of activated sludge}

To prevent surface and underground water pollution, waste water treatment is essential. Such treatment using intermitted aeration process is efficient in removal of organic substances such as Biochemical Oxygen Demand (BOD), Total Organic Carbon (TOC), Total Nitrogen (TN) and Total Phosphorus (TP) and regulate the emission of nitrous oxide, a greenhouse gas (IPCC, 1995)

\section{(vii) Proper animal waste management and disposal}

Collection of animal wastes is the first step in waste disposal. The properties of collected wastes are determinants in the choice of disposal options. Most beef cattle and chicken waste is in solid or semi solid form, therefore, it can be removed easily. With pig and diary cattle raised on concrete floor, theirs has to be cleared out by water. There are a large number of ways for animal waste disposal. The choice is highly dependent on the housing design and ways of cleaning and some region, the religious taboo. Producers should therefore establish a right sense of taking up the responsibility for proper waste disposal.

(viii) Efficient livestock nutritional management A valuable option in developing an environmentally sound waste management is through nutritional management. It includes proper feeding programmes and feeds which will result in less excreted nutrients that need to be managed. Critical components to be controlled are N, P and minerals that are used in supranutritional level. This can be achieved through amino acid supplementation and protein restriction that will reduce $\mathrm{N}$ excretion in monogastric animals. Supplementation of enzymes such as carbohydrates, phytase and protease can be used to reduce excretion of nutrients and feaces by improving digestibility. Use of growth promoting agents and deodorases are other available ways but this will increase costs of production.

(ix) Use of biological technology

The industrial scale implies large herd or flock sizes, large volume of waste and high concentration of environmental hazard with the biggest problem having to deal with the over-concentration of animals in areas of high human population density with little, viable opportunities to utilize waste products on land. This requires specialized technology such as:

\section{(a) Recovery of nutrients from waste using invertebrates}

The biological digestion of livestock manure by invertebrates appears to be a solution to the accumulation of large amount of waste if reasonable technological processes can be developed in Nigeria. Boda (1990) reported that $80 \mathrm{~kg}$ of dungworms biomess can be produced per ton of cattle dung. Omoyakhi \& Nwokoro (2004) noted that layer manure can yield a total of $12.59 \%$ of maggot. Dried ground housefly maggot meal crude protein $(56.63 \%)$ was higher than that of soybean (48.505) when compared. Several other authors' reports indicated that no disease symptom or mortality was observed when these invertebrates grown on manure were used as livestock feed (Atteh \& Oyedeji, 1990; Koo et al., 1980). Generally, during digestion of manure, the invertebrates convert the sticky mass of manure into an odourless loose crumbly products which can easily be disposed. The digestion of poultry manure by the larvae reduced the moisture content from $80 \%$ to $55 \%$ and removed about $80 \%$ of the organic matter resulting into odourless, loose and crumbly texture (Omoyakhi \& Nwokoro, 2004). 


\section{(b) Production of single call protein}

Single call protein (SCP) can be obtained from microorganisms resulting from biosynthetic activities of these organisms. These microbial proteins can be cultivated on cheap agricultural byproducts, principally manure from livestock. The technologies are cheap and simple. The values of the chemical composition of these SCP like protein $23-65 \%$, carbohydrate $4-33 \%$, lipids i.i-308\%, ash $4.2-9.0 \%$ and fibre $2.2-3.4 \%$ make them economically attractive for feed formulation (Hama \& Miyachi, 1988).

\section{(c) Production of biogas}

Biogas (domestic gas) can be produced anaerobically from livestock waste.. Itodo, et al., (2001) estimated that 3.27, 0.01 and 0.26 million cubic metric of biogas can be generated from cattle, poultry and piggery waste respectively per day in Nigeria if annexed. Olomu \& Oboh (1995) noted that the effluent from 10 matured pigs will provide enough methane gas for the energy needs of a family of 6 to 8 . A household biodigester (for biogas production), about $19 \mathrm{~kg}$ of dung per day is required for the domestic energy consumption (Anyanzo, 2005). In the biodigester, the organic materials is fermented by bacteria, producing biogas and slurry. Biogas is seen as a good alternative source of energy for cooking and lighting. Since it was manure, it improves the sanitation of the homestead and saves time use in collecting scarce firewood. It is also safer than the commercial gases. (Anyanzo, 2005).

\section{(d) Biodigestion for the production of high quality fertilizer}

In the past, biodigestion has been considered mainly as a way to produce combustible gas from waste organic matter. Because of increasing emphasis on the sustainable use of natural resources in farming system, it is now appreciated that biodigestion is considered in a much wider perspective and specifically, in the potential role for the recycling of plant nutrient (Preston, 2005). The by-products of the anaerobic decomposition that takes place in a digester occur in two fractions, the liquid fraction called the biol and the solid fraction or biosol. Both are excellent fertilizers for a variety of crops (Osorio, 2005). The biol contains many essential elements for plant growth such as nitrogen, phosphorus, potassium and calcium. It also offers additional benefits to plant because it contains plant growth regulators such as auxines and gibberelin, as well as other substances that stimulate plant development. The solid part, biosol has similar nutrient contents. Both fertilizers favour rooting, the development of the foliage and flowering and activate seed germination (Osorio, 2005). Farmers can easily modify the nutrient content of the liquid fertilizer, for example, by adding chopped alfalfa, fish entrails and marine seaweed to the digester. The ready made biol can also be enriched with mineral salts to provide additional nutrients to a crop or for other liquid fertilizer to control diseases such as leaf rust in coffee crops. Biol is easily applied to crops directly to the foliage as liquid fertilizer with a backpack sprayer or to the irrigation water. Biosol can be applied directly to the plant just as one would apply compost.

Conclusion: It is obvious in the light of the above that both the government, animal scientists, livestock producers and environmentalists have their share responsibility for the public safety and the protection of the environment. Therefore, urgent and decisive action is needed to conserve and maintain the ecosystem with a view to the sustainable management and the use of biological resources. Formulating and enforcing some of the above policies and management would mean more than fighting pollution and degradation but unconsciously engaging in the use of cheap alternative resources for human development. An objective, consistent and continuous maintained environment-livestock management is the only answer to our problem of environmental protection for us today and for our children tomorrow.

\section{REFERENCES}

Addiscott, TM, Whitemore, AP; Powlson, DS (1991). Farming, Fertilizers and the nitrate problem. C.A.B. International, Walling Ford, U.K. pp 170

Ademoroti, CMA (1996). Environmental Chemistry and Toxicology. Pp $63-91$

Anon, A (1982). Ecological aspects of development in the Humid Tropics: Committee on selected Biological problem in the Humid Tropics, Division of Biological Sciences. Assembly of Life Sciences Natural Research Council, Nigeria.

Anyanzo, AR (2005). Biogas in Uganda: A new experience. LEISA $21(10$ p 13

Atteh, JD; Oyedeji, JO (1994). The replacement value of maggots for groundnut cake in broiler diet. Centre point. 10: $39-46$

Boda, K (1990). Non-conventional feedstuff in the nutrition of farm animals. Elsevier, New York pp. $155-170$

Catelo, A, Moises, A Dorado; Elpidio, A (2001). Living with livestock: Dealing with pig waste in the Philippines. Summary of EEPSEA Research Report 2001.

Conway, GR; Pretty, JN (1991). Unwelcome Harvest Agriculture and Pollution. Earth Sean Publication Ltd., London. 
Darwin, R (2001). Climate change and food security: In Agriculture information Bulletin No 765 768: Issues in Food Security. United States Department of Agriculture.

De Hean, C (1996). Range and development in developing world. Proceeding of the Fifth International Rangeland Congress. Society for range management. Denver, Colorado, USA.

Early, MSB, Cameroon, KC; Fraser, PM (1998). The fate of potassium, calcium and magnesium in stimulate urine patches on irrigated dairy pasture soil. New Zealand J. Agric. Res. 41: $117-124$.

FAO, (1996). Livestock and the environment: Finding a balance FAO/World bank Project.

Hama, T; Miyachi, S (1988). Microagal Biotechnology. Ed. M.A. Borowitza and L.J. Boroworzka. Cambridge University Press. Cambridge. UK pp 235- 239.

Harada, Y (1994) Treatment and utilization of animal wastes in Japan. Project Research Tech No 6. Nature Agriculture Research centre. Kannondai 3 -1-1,Tsu Kuba 305, Japan.

IPCC, 1995 Intergovermental Panel on Climate Change. US Dept of the interior/ US Geological Survey. http://geochange.er.usqs.gov/sw/changes/ authoropogenic/ipec-b/

Itodo, IN, Awulu, JO; Philip, T (2001). A comparative analysis of biogas yield from poultry, cattle and piggery wastes. African J. Environmental studies 2(1): 152 - 154

Oldeman, LR, Hakkeling, RTA; Sombroek, WG (1991). World map of the status of human induced soil degradation. An explanatory date. ISRIC/UNEP, Wagrningen. The Netherlands.
Olomu, JM; Oboh, SO (1995). Pig Production in Nigeria: Principles and Practice. A JACHEM publication. $150 \mathrm{pp}$

Omoyakhi, JM; Nwokoro, SO, (2004). Yield and chemical composition of maggot meals obtained from droppings of farm animals. Nigeria poultry Sci. J. 2: $52-57$.

Osorio, LG (2005). Improving organic fertilizers. Low External Input and Sustainable Agriculture 21 (1): $14-15$.

Preston, TR (2005). Biodigesters in ecological farming systems. Low External Input and Sustainable Agriculture 21 (1): $8-10$

Rosenzweig, C; Hillel, D (1998). Climate change and the global harvest. New York Oxford University Press.

Sangodoyin, AY (1996). Nutrient benefits and environmental aspects of land disposal of livestock waste. J. Environmental Management and Health, 7(1): $33-38$

Whitemore, AP ( 2001). Impact of livestock on soil. www.andywhitemore.com

Zhang, R; Felman, D (1997). Animal manure management - Agricultural Scoping Study. The EPRI Agricultural Technology AllianceElectric Power Research Institute C109139. 